\title{
The Role of Involvement as a Moderating Variable in a Country of Origin Study
}

\author{
Rindang Matoati ${ }^{1 *}$ and Suci Paramitasari Syahlant ${ }^{2}$ \\ 1) Faculty of Economics and Management Bogor Agricultural University, Indonesia \\ 2) Faculty of Animal Science Universitas Gadjah Mada, Indonesia
}

\begin{abstract}
The aim of this study is to examine the effect that the country of design and the country of manufacture has on the perceived quality of a product, and the role of involvement as a moderating variable. The conceptual framework has been tested using laboratory experiments that included a $2 \times 2 \times 2$ between the subject's factorial designs. Participants were assigned by using a randomization method and data was analyzed using a one-way and two-ways ANOVA. The results indicated consumers' involvement, as a moderating variable, limited the strength of the country of design and the perceived quality's relationship as this relationship is found to be stronger in circumstances where the consumers' involvement was greater than in the less involved group's condition. However, consumers' involvement did not have any role as a moderating variable in the relationship between the country of manufacture and the perceived quality.
\end{abstract}

Abstrak: Tujuan penelitian ini untuk menguji pengaruh negara asal desain dan negara produksi pada kualitas produk. persepsian, dan peran keterlibatan sebagai variabelpemoderasian. Penelitian ini menggunakan desain eksperimen laboratorium, yaitu desain faktorial $2 \times 2 \times 2$. Partisipan dibagi ke dalam kelompok eksperimen dengan metode randomisasi dan data dianalisis dengan uji one-way dan two-way ANOVA. Hasil menunujukkan peran keterlibatan konsumen, sebagai variabel pemoderasian, membatasi kuatnya hubungan antara negara asal desain dan kualitas persepsian, karena hanya pada kondisi keterlibatan tinggi, negara asal desain berpengaruh pada kualitas persepsian. Namun, ketelibatan konsumen tidak mempunyai peran pada bubungan negara asal produksi dan kualitas persepsian.

Keywords: country of design; country of manufacture; perceived quality

JEL classification: M310

* Corresponding author's e-mail: r.matoati@gmail.com 


\section{Introduction}

The impact of globalization on the industrialized world has caused competition among companies to become much tougher. Indonesia has entered into the ASEAN Economic Community (AEC), in which the ASEAN nations are transformed into a highly competitive group with a single market and production base. Furthermore, domestic manufacturers are expected to grow accordingly, in order to face the new competition. An alternative way to prevail against the competition is by maintaining or improving the quality of the products being produced (Voorhees 2013). Products which are perceived as being of a poor quality, or have a negative connotation, and are not preferred by consumers, are not going to compete with other products which may have better marketing strategies implemented by their manufacturers. However, products of an inferior quality will not out-compete better ones, even if they have the best marketing strategy. Indeed, there are benefits in emphasizing the importance of maintaining a product's perceived quality, as this can increase its premium price, market share and hence profit (Aaker 1991: 89). Marketers should note a product's quality in order to surpass its competitors.

The consumers' perceived quality of a product changes over time due to increasing information, new competition in each category of products, and changes in the customers' expectations (Zeithaml 1988). Remodeling products by adding new features, changing their physical appearance, or taste, cannot change consumers' perceptions or evaluations of their quality. Therefore, marketers must understand the consumers' perceptions every time and align their strategies and products' promotions in line with the changes in the consumers' perceptions.

Recently, the country of origin is one of the extrinsic cues that is now essential to use to assess a product's quality (Ahmed and d'Astous, 2008). Extrinsic cues are the nonphysical characteristics of the products, such as price, brand name and country of origin (Zeithaml 1988). The country of origin creates mental associations and beliefs triggered by that country's name (Kotler and Keller 2013: 636). Knowledge of the country of origin of a product is very important for consumers to assess that product's quality, as the perception of a country could change at any time, and may result in either a negative or positive image (Keegan and Green 2011: 344).

On the other hand, Liefeld (1993) has shown that the country of origin has no significant effect on the perceived quality. This can be explained by the fact that consumers are not able to determine products by their country of origin, and the issue becomes more prominent when companies have an outsourcing strategy which uses a country as a place to manufacture various components of their product. Therefore, the influence of the country of origin cannot always be associated with the manufacturing locations in a country, and multidimensional research into the country of origin is absolutely necessary to show the actual market conditions (Hamzaoui and Merunka 2006). Customers' perceptions may change substantially as the product could well be designed in one country, have its parts manufactured in another, and then assembled in a third different county (Chowdhury and Biswas 2011). Essoussi (2010) used the concept of the country of design and manufacture to assess the quality of a product. The country of design is that 
state's ability to plan, design and develop products, while a country of manufacture is the ability of a state to create or assemble a product. Hence, the concept of the country of origin turns into a segmented idea, the customer has different perceptions of a product which may be designed and manufactured in different locations.

Pharr (2005) emphasized the importance of moderating factors in explaining the inconsistent effect of countries of origins' influence. Involvement is logically possible as one of the variables that moderate the influence the country of origin has on perceived quality. Fischer et al. (2012) explaines that once consumers feel deeply engaged with a product, so all information would not bemissed in order to evaluate the product. However, involvement itself as a moderating variable still causes inconsistent results when explaining the relationship between the country of origin and the perceived quality. For example, research conducted by Josiassen et al. (2008) and Lee et al. (2005) shows different results. Josiassen et al. (2008) identified that low consumer involvement with the product would strengthen the evaluation of the product's quality but in this case, the consumers tend to search for all the information related to the product's content or intrinsic attributes, but not to the extrinsic attributes such as its origin and price and brand. Ahmed and D'astous (2008) and Lee et al. (2005) found different results; that greater consumer involvement with the product would trigger the consumers to consider all the product's attributes including its country of origin when evaluating the product. Therefore, it is important to re-examine the assessments of the role engagement plays with consumers' involvement in moderating the country of origin's effect on the perceived quality.
Previous studies show that consumer involvement, as a moderating variable, has been examined to a limited extent for unidimensional countries of origin (Josiassen et al. 2008; Josiassen 2010; Abraham 2013). Essoussi (2010) used complexity technology that refers to technological advancements in the production process, as a moderating variable for the effects of the country of design and manufacture on the perceived quality. As described above, in relation to the changing country of origin's paradigm, it is important to test the moderating effect of consumers' involvement when explaining the effects of multidimensional countries of origin, namely the effects of the countries of design and manufacture on the perceived quality.

The aim of this study is to examine the effects of the country of design and country of manufacture on the perceived quality, and the role of consumers' involvement as a moderating variable for the product.

\section{Literature Review}

The country of origin, also commonly known as "made in," is one of the intriguing aspects of a product. The country of origin is associated with a country's ability to manufacture certain products. In line with the changes made because of marketing strategy considerations, and business cooperation between countries, these now give manufacturers the latitude to be able to produce, assemble and design their products in different countries, Chowdhury (2010) reveals that in the era of global brands, the country of origin has become much more complicated, hence the need to use a multidimensional approach to the country of origin of a product. 
Consumers' perceptions of a product are associated with the country that designs/ manufactures it. If the consumers' perception of that country's ability to design a product is low (poor), then the lower the consumers' perceived quality of that product will be (Essoussi and Merunka 2007). Relocating a product's manufacturing site can be financially rewarding. However, it can raise important issues relating to the products perceived quality by its consumers (Essoussi and Merunka 2007). Consumers generally prefer products made in developed countries, rather than those manufactured in developing countries (Saffu and Scott 2009). Investigators have alleged that the better the perceptions of a country are, which has the ability to manufacture a product, those perceptions will improve the perceived quality of the product. On the other hand, a country with a considerably poorer image for making products, as viewed by consumers, will see the perceived quality of its products reduced. Therefore, this study proposes two hypotheses as follows:

$H_{i}$ : The perceived quality of a product designed in a country with a superior image is better than that designed in a country of origin with a lesser image.
$H_{2}$ : The perceived quality of a product whose country of manufacture has a superior image is better than a product from a country of manufacture with a lesser image.

Multidimensional studies of the country of origin of a product with a high level of involvement indicate that the product's quality, from a highly perceived country of origin, will be better than that of a product with a low level of involvement (Saffu and Scott 2009). Chueh and Kao (2004) revealed that by involving consumers, in an effort to collect information about a product, the consumers would allocate their own time to this information gathering, so that their engagement will moderate the influence of the country of origin on the product's quality design. Lee et al. (2005) revealed that the effects of a situational involvement will affect the assessment of a product's quality, when a high level of consumers' involvement is attached to the product (enduring involvement). The country of origin's effect is stronger when consumers evaluate a product with a higher level of involvement (Henderson and Hoque 2010). Consumers with a high level of involvement are more careful when seeking information about the country of origin, and the influence of a multidimensional country

Figure 1. Research Model

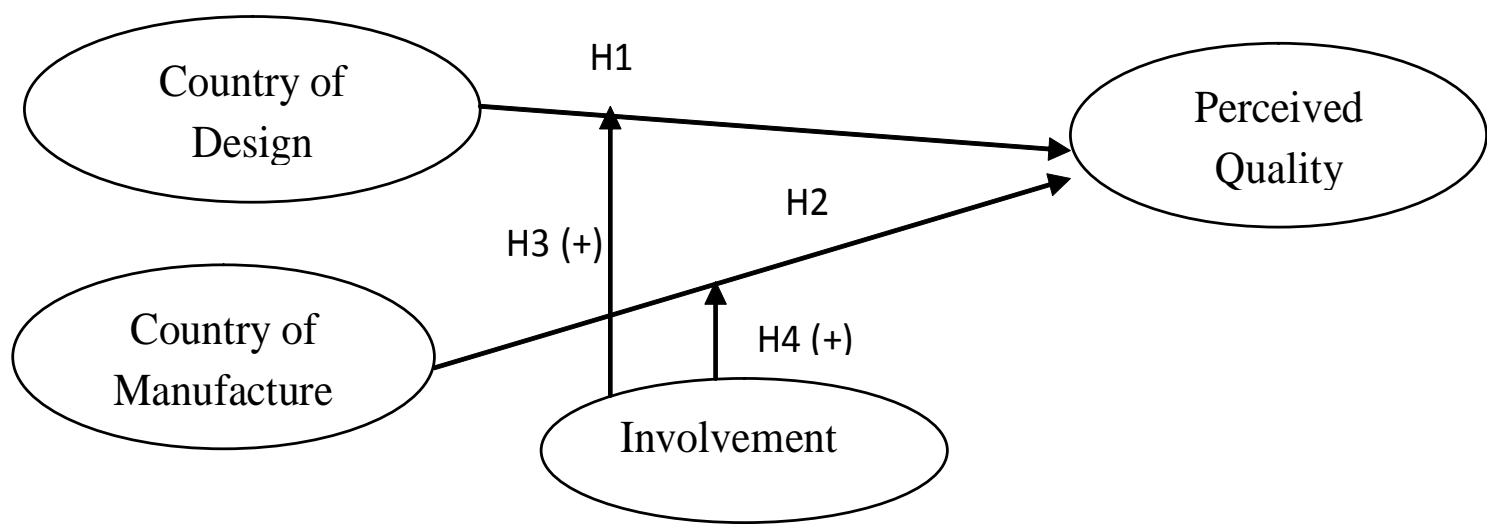

Source: Chueh and Kao (2004); Lee et al. (2005); Pharr (2005) 
of origin in which the country of design and the country of manufacture are stronger in the presence of personal involvement as a moderating variable. Therefore, this study developed the next hypotheses as follows:

$H_{3}$ : The differences in the perceived quality of a product from its country of design are moderated by its levels of involvement. A higher level of consumers' involvement with the product has a stronger influence when considering its country of design and the perceived quality's relationship.

$H_{4}$ : The differences in the perceived quality of a product from its country of manufacture are moderated by its levels of involvement. A higher level of consumers' involvement with the product has a stronger influence when considering its country of manufacture and the perceived quality's relationship.

\section{Methods}

\section{Pre-test}

Several pre-test studies were performed to ensure the conformity of the product and some other information relevant to the research's context. The first pre-test study $(n=27)$ was conducted to select a product by asking people to name 10 products that they had decided to purchase, based on reading the information printed on the product or its packaging. This data were then categorized into two groups of products, namely personal care products (bath soap, toothpaste and shampoo) and fashion (shoes, bags, perfume, trousers, shirts, watches, and jackets). Perfume was one of the products that had frequently been mentioned by our respondents (18 times in total) therefore we chose it as the research object. Another consideration is that perfume does not have any sub-category of products, unlike for example shoes, which can be divided into sub-categories such as sport shoes, casual shoes or formal shoes. Any sub-category could potentially harm our experimental bias.

The second pre-test was carried out to confirm the product category of perfume. Thompson and Haytko, (1997) define fashion "as a value system that explains the ethos of modernity, self-improvement, status and social mobility." Based on this definition, perfume can be categorized as a fashion product. However, several previous studies had incorporated perfume into different product categories, such as it being a cosmetic product (Fah et al. 2011), while Sadeghi et al., (2011) listed it as a body treatment. Therefore it is important to define the object that is used in this research. Confirmation of perfume's place as an item of fashion was done by questioning a number of people ( $\mathrm{n}$ $=25$ ) about various alternative product categories for perfume and the pre-test results confirm that perfume is considered a fashion product. This result is consistent with Seitz (1998) who defined perfume as a fashion product.

The next pre-test was conducted to determine the country of origin $(\mathrm{n}=34)$, to decide which countries produce perfumes. Several countries producing perfume were identified, based on market reports detailing the export and import of perfume in Asia in 2011 (Parker 2011). We added Indonesia to the list as a perfume manufacturer, considering that the research is being conducted in Indonesia, and some perfume brands are also manufactured in Indonesia. The selection of the country of design and manufacture was based on the frequency of replies to our question. France was perceived as a desirable country of design and country of manufac- 
ture, while Indonesia was seen as both a poor country for the design and manufacture of perfume.

\section{Manipulation Check}

A manipulation check was conducted to determine that the researcher and the participants had the same perceptions about our experimental treatments, that the levels of the country of design and the country of manufacture were agreed, meaning France is regarded as a desirable country of design and country of manufacture for perfume, and Indonesia is viewed as a poor country of design and manufacture. This procedure checks if manipulation is present by displaying a printed perfume advertisement for a new brand of perfume, which has information about where the product is manufactured and designed, namely in France or Indonesia. All the displayed information is created equally in all the experimental treatments except for the name of the country where it is designed and manufactured, in other words France or Indonesia. Here is a picture of the perfume products which are used as stimuli.

Subjects were asked to observe a print advertisement for a perfume brand called "Ëau de Perfume" and then fill out a questionnaire which contained a three-point statement of how logical, reasonable and appropriate the design and production capability of the two countries were (Hamzaoui and Merunka 2006), in this case France and Indonesia. The researcher used an independent sample t-test to analyze the differences between France and Indonesia as the designer and producer of the given perfume product.

\section{Figure 2. Sample of the Experimental Stimuli with France as the Country of Design and Country of Manufacture}

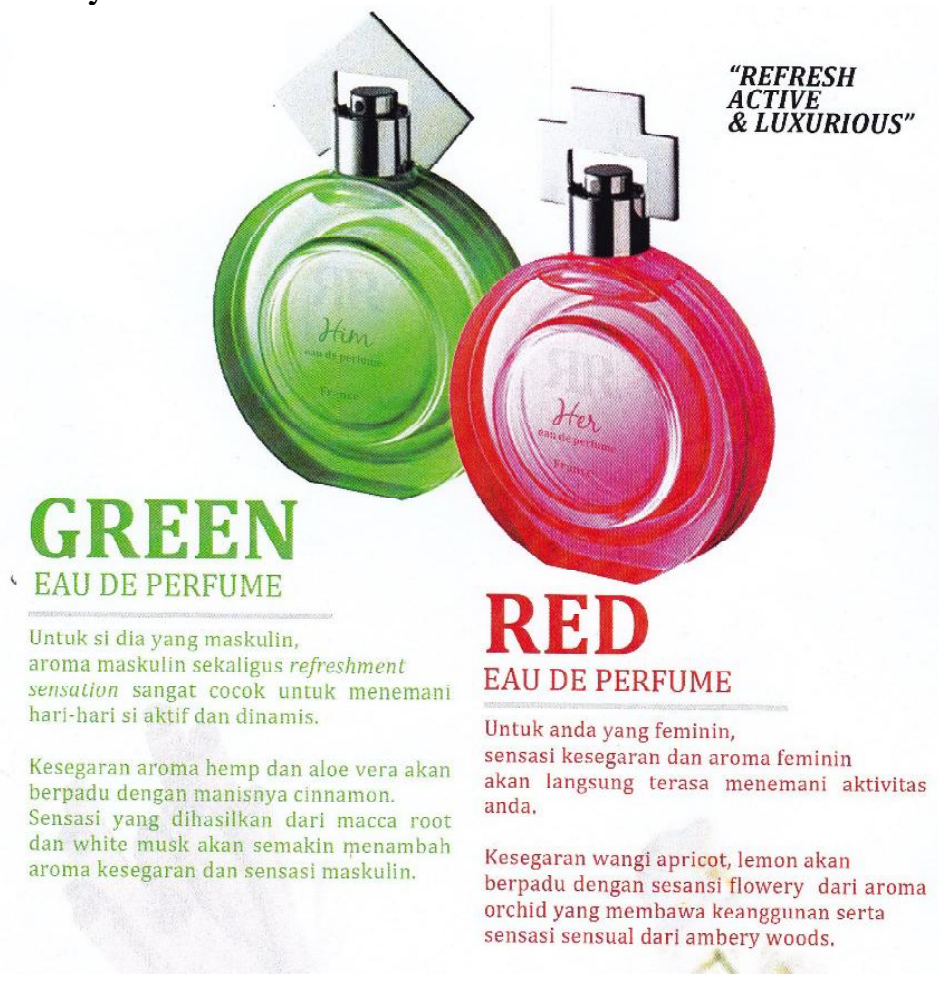


Table 1. Results of the Manipulation Check's Independent Sample T-Test on the Country of Design and Country of Manufacture

\begin{tabular}{cccccc}
\hline Variable & $\begin{array}{c}\text { Participant } \\
\text { (N) }\end{array}$ & Mean & $\begin{array}{c}\text { Mean } \\
\text { Differences }\end{array}$ & t- value & Sig. (2-tailed) \\
& & &
\end{tabular}

High Country of Design

\begin{tabular}{lccccc} 
(France) & 26 & 4.277 & 0.8160 & 3.513 & 0.010 \\
$\begin{array}{l}\text { Low Country of Design } \\
\text { (Indonesia) }\end{array}$ & 23 & 3.261 & & & \\
$\begin{array}{l}\text { High Country of Manufacture } \\
\text { (France) }\end{array}$ & 22 & 3.758 & 0.4489 & 2.128 & 0.039 \\
$\begin{array}{l}\text { Low Country of Manufacture } \\
\text { (Indonesia) }\end{array}$ & 27 & 3.309 & & & \\
\hline
\end{tabular}

The result, as shown in Table 1 , describes a common perception among the respondents that France is perceived as being significantly more capable $(\mathrm{M}=4.277)$ than Indonesia $(\mathrm{M}$ $=3.261)$ of designing $(\mathrm{p}<0.05)$ and producing $(\mathrm{M}=3.758$ to $\mathrm{M}=3.309)(\mathrm{p}<0.05)$ this perfume. Therefore, France is confirmed as being a "high" country of design and country of manufacture while Indonesia is a poor country of design and country of manufacture for this Eau de Perfume product.

\section{Subjects and Procedure}

This study was implemented using the laboratory experimental design method, in accordance with a study conducted by Sekaran and Bougie (2010, h.228) in a regulated artificial enviroment. The main study consists of 229 subjects who were assigned in a $2 \times 2 \times 2$ between the subject's factorial designs. The country of design and manufacture was experimentally treated and manipulated by the researchers, while involvement was measured and divided using a median split after the participants had been exposed to the treatment.
The research's participants were undergraduate students aged from 17 years and upwards. The reason for using students as the participants was based on previous research by Wong et al. (2008). This research was carried out in China and also used students as its participants. Students comprise part of the young potential market for perfume products, and about half of Indonesia's population is below 30 years of age (Montlake 2013: 29), therefore using this young student population can be the surrogate for the population as a whole. There were six steps in the participants' selection process. Firstly, the participants were chosen by a randomization method in SPSS for Windows version 16.00. Secondly, the participants were approached in a haphazard manner and given a coupon by the researcher, this was done to shorten the time period of the experiment. Thirdly, the researcher called on the participants, one by one. Fourthly, the participants were classified into four treatment groups. Fifthly, the participants observed and evaluated the perfume's advertising, and answered questions about the product's quality, to measure the levels of the consumers' involvement with 
Table 2. Matrix of Experimental Design

\begin{tabular}{|c|c|c|c|c|c|}
\hline \multirow{6}{*}{ Country of Design } & \multicolumn{4}{|c|}{ Involvement } & \multirow{6}{*}{ Country of Manufacture } \\
\hline & & High & Low & & \\
\hline & \multirow[t]{2}{*}{ High } & A & B & High & \\
\hline & & $\mathrm{C}$ & $\mathrm{D}$ & Low & \\
\hline & \multirow[t]{2}{*}{ Low } & $\mathrm{E}$ & $\mathrm{F}$ & High & \\
\hline & & G & $\mathrm{H}$ & Low & \\
\hline
\end{tabular}

the product, since personal involvement had not been assigned as a treatment in the experiment. Then for the final step we measured and used a median split to divide the participants into two-group subjects (high and low personal involvement), so that the participants could be classified into eight groups.

The research stimuli were the perfume's print media advertisements. The specific brand of perfume used was a hypothetical brand named "RR Eau de Perfume" to avoid any familiarity with existing brands' bias. The advertisements contained information about the product itself and its country of design and country of manufacture. All the information, except for the name of the country of design and manufacture were kept exactly the same. Syahlani and Citra (2008) revealed in their study that the influence of the country of origin would reduce if there was other information attached to a product.

To test the hypotheses, an experiment was conducted by using paper and a pencil. The participants were grouped into four random groups, and each group was given one treatment of the image which included where the product was designed and manufactured. Then, the participants assessed the quality of the perfume based on a print media advertisement. To prevent any bias from gender, the perfume pictured in the treatment was divided into two types, for males and females.
The participants analyzed both types. To give a clearer picture of the experimental design, it is shown in Table 2.

\section{Measures}

The questionnaire was developed to measure the perceived quality of the product, which is defined as the consumers' overall assessment of the advantages of the product, or the product's superiority (Zeithaml 1988). The measurement used was adopted from Dodds et al. (1991) who developed a perceived quality measurement with 5 point statements to assess customers' trust in the product, the product's quality, their evaluation of the scent, the product's capability and the product's reliability.

The measurement was also designed to measure the moderating variable used in this experiment, namely the consumers' involvement, which was adopted from the work of Jain and Srinivasan (1990), which assessed the interest, attention to and the information search process of individuals associated with certain products. Laurent and Kapferer (1985) explain that involvement is an individual difference variable that motivates people's purchasing and communication behaviour, but has a number of consequences. Therefore, it can be assumed that one product might result in different levels of consumer involvement, as they have dif- 
ferent levels of personal factors that might apply to the buying decision making process.

\section{Analysis}

A confirmatory factor analysis and Cronbach's Alpha were employed to measure the validity and reliability of the measurement. An independent sample T-test was used to examine the manipulation check, and finally, an ANOVA test was conducted to find the differences between the subjects in the sample. An indicator test, a one-way ANOVA and a two-way ANOVA used a significance level $(\alpha)$ of 5 percent or 0.05 . The hypotheses will be accepted if $p$ is equal to or less than 0.05 , while they will be rejected if the $\mathrm{p}$-values are greater than 0.05 .

\section{Result and Discussion}

There are four proposed hypotheses to test the effect of the country of design and manufacture on the perceived quality, and to test the moderating effect of the consumers' involvement on the relationship between the country of design and manufacture and the product's perceived quality. Table 3 shows that $\mathrm{H}_{2}$ and $\mathrm{H}_{3}$ are supported, as shown by their $\mathrm{p}$ values being $<0.05$ while $\mathrm{H}_{1}$ and $\mathrm{H}_{4}$ are not supported as their $\mathrm{p}$ values are $>0.05$.

$\mathrm{H}_{1}$ testing showed that there is no difference in the perceived quality between a high and low country of design. This result supports the research conducted by Essoussi (2010) that revealed the technological complexity of the production process can affect the relationsip between the country of design and the perceived quality. The technology used to develop perfume products is easily adapted, and now perfumes are not only designed in France, but many other countries are also designing perfumes, such as Japan, the U.S., and Italy (Moeran 2005). Hamzaoui and Merunka (2006) revealed that the country of design has an influential role when a consumer has a high level of involvement, because of the feeling of being associated with the country's prestige and social status. To fulfill this requirement, consumers will look for information, and the role of the

\section{Table 3. Hypotheses Testing Result}

\begin{tabular}{|c|c|c|c|}
\hline $\begin{array}{l}\text { Hypotheses } \\
\text { Code }\end{array}$ & Hypotheses statement & $\mathbf{P}$ value & Results \\
\hline $\mathrm{H}_{1}$ & $\begin{array}{l}\text { The perceived quality of a product designed in a country with } \\
\text { a superior image is better than that designed in a country of } \\
\text { origin with a lesser image }\end{array}$ & 0.418 & Rejected \\
\hline $\mathrm{H}_{2}$ & $\begin{array}{l}\text { The perceived quality of a product whose country of } \\
\text { manufacture has a superior image is better than a product } \\
\text { from a country of manufacture with a lesser image. }\end{array}$ & 0.009 & Accepted \\
\hline $\mathrm{H}_{3}$ & $\begin{array}{l}\text { The differences in the perceived quality of a product from } \\
\text { its country of design are moderated by its levels of involvement. }\end{array}$ & 0.0496 & Accepted \\
\hline $\mathrm{H}_{4}$ & $\begin{array}{l}\text { The differences in the perceived quality of a product from its } \\
\text { country of manufacture are moderated by its levels of involvement. }\end{array}$ & 0.320 & Rejected \\
\hline
\end{tabular}


country of design needs to be part of that information.

A different result was shown for the country of manufacture $\left(\mathrm{H}_{2}\right)$. The hypothesis which states that the perceived quality of a product from a country of manufacture with a superior image is better than from a country with a lesser image is supported. The participants noticed significant differences between the perfumes produced in Indonesia and France. This is consistent with research conducted by Stafu and Scott (2009). Their research revealed that in certain countries personal fulfillment is derived from imported goods, because the consumers have a tendency to choose products that come from countries which are perceived to have a superior image, rather than products manufactured in their own country. The people in these countries are not familiar with their own home produced products. This could also occur in Indonesia, which has been flooded with imported products after making free trade agreements with different countries. Therefore, the country of manufacture is the dominant factor in a product's perceived quality assessment.

The hypothesis that states that the differences in the perceived quality of a product from its country of design are moderated by the level of the consumers' involvement $\left(\mathrm{H}_{3}\right)$ is also supported. The more consumers became involved with a product, the greater is the effect of the country of design on the perceived quality (Figure 3). The changes in the level of involvement led to changes in the mean values of the perceived quality for superior and lesser countries of design. Table 4 shows the results indicating the interaction of involvement on the relationship between the country of design and the perceived quality $(\mathrm{F}=3.8973 ; \mathrm{p}=0.0496<0.05)$.

Figure 3 shows that high involvement strengthened the relationship of the country of design and the perceived quality of the product (mean difference $=0.227$ ), compared to the interaction between the country of design and the perceived quality with low levels of consumer involvement (mean difference $=0.106$ ). The moderation effect works when the relationship between the independent and dependent variable is influenced by the existence of another variable, which is the moderating variable (Nahartyo 2012: 118). The different levels of consumers' involvement impact differently on the perceived quality from high and low level countries of design. Figure 3 shows that in the high involvement group, perceived quality increases with a change in the level of the country of design. In other words, participants notice the

Tabel 4. Analysis of Consumers' Involvement as a Moderating Variable on the Relationship between Country of Design and the Perceived Quality

\begin{tabular}{lcccccccc}
\hline $\begin{array}{l}\text { Dependent } \\
\text { Variable }\end{array}$ & $\begin{array}{c}\text { High Country } \\
\text { of Design }\end{array}$ & Mean & N & $\begin{array}{c}\text { Low Country } \\
\text { of Design }\end{array}$ & Mean & N & $\begin{array}{c}\text { F } \\
\text { Statistic }\end{array}$ & P \\
\hline $\begin{array}{l}\text { Perceived } \\
\text { quality }\end{array}$ & High Involvement & 3.371 & 68 & High Involvement & 3.144 & 54 & 3.8973 & 0.0496 \\
& Low Involvement & 2.920 & 60 & Low Involvement & 3.026 & 47 & & \\
\hline
\end{tabular}

Source:Proceed Data (2012) 
different levels of the country of design and absorb all the information contained in the printed advertisement more carefully. Contrarily, participants in the low involvement group did not notice the difference in the level of the country of design and even assesed products from a higher country of design as having a lower perceived quality.

The last hypothesis stated that the differences in the perceived quality of a product from its country of manufacture are moderated by the levels of involvement is not supported. Figure 4 shows that the interaction's line between involvement and the country of manufacture is parallel. Changes from a low involvement condition (low involvement; the mean of a low country of manufacture $=2.893$, while the mean of a high country of manufacture $=3.047$ ) to a high involvement level (high involvement; the mean of a low country of manufacture $=$ 3.134 , the mean of a high country of manufacture $=3.454)$ did not lead to a different pattern. As shown in Table 5 this interaction does not occur, thus hypothesis 4 is not supported $(\mathrm{F}=0.922 ; \mathrm{p}=0.320>0.05)$. Essoussi (2010) explains that consumers in developing countries are more familiar with the country of manufacture idea. Indonesia, as a developing country which is growing rapidly (Charitaou et al. 2012), generally considers developed countries to be superior than the developing countries currently are at producing products. Therefore, because of the familiriaty with the "made in" concept, consumers are more focused on information about the country of manufacture, and it has no difference even with high or low levels of involvement as shown in Table 5. Figure 4 shows that consumers with low and high involvement have similarities when assesing the country of manufacture, which they valued higher for a "high" country of manufacture, and vice versa.

\section{Figure 3. Interaction Relationship between Involvement and Country of Design}

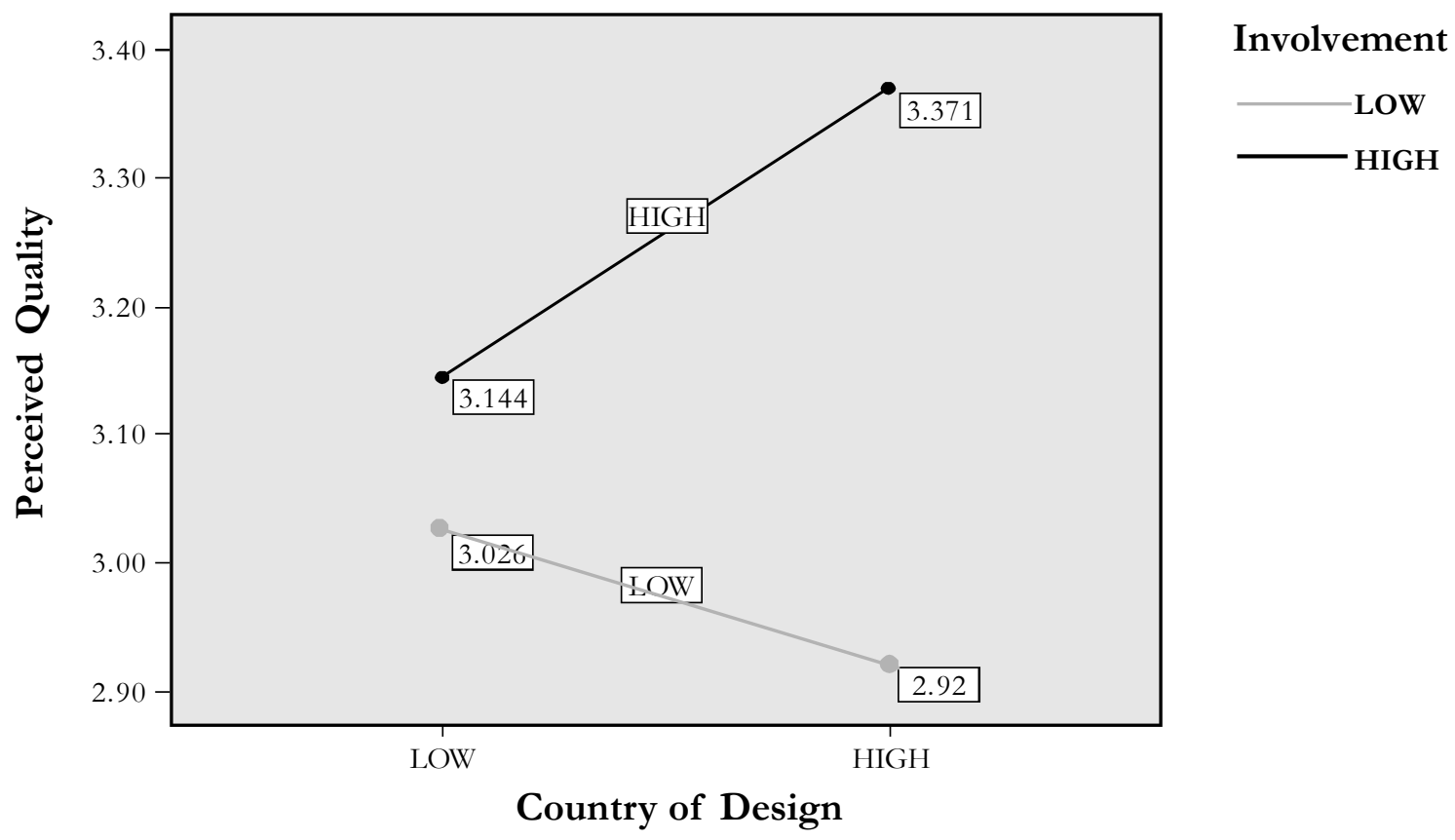


Tabel 5. Involvement Slope as Moderating Variable between County of Manufacture and Perceived Quality

\begin{tabular}{lcccccccc}
\hline $\begin{array}{l}\text { Dependent } \\
\text { Variable }\end{array}$ & $\begin{array}{c}\text { High Country } \\
\text { of Manufactruring }\end{array}$ & Mean & N & $\begin{array}{c}\text { Low Country } \\
\text { of Manufactruring }\end{array}$ & Mean & N & $\begin{array}{c}\text { F } \\
\text { Statistic }\end{array}$ & P \\
\hline $\begin{array}{l}\text { Perceived } \\
\text { quality }\end{array}$ & High Involvement & 3.454 & 52 & High Involvement & 3.144 & 70 & & \\
& Low Involvement & 3.047 & 51 & Low Involvement & 2.893 & 56 & 0.992 & 0.320 \\
\hline
\end{tabular}

Source:Proceed Data (2012)

Figure 4. Interaction Relationship between Involvement and Country of Manufacture

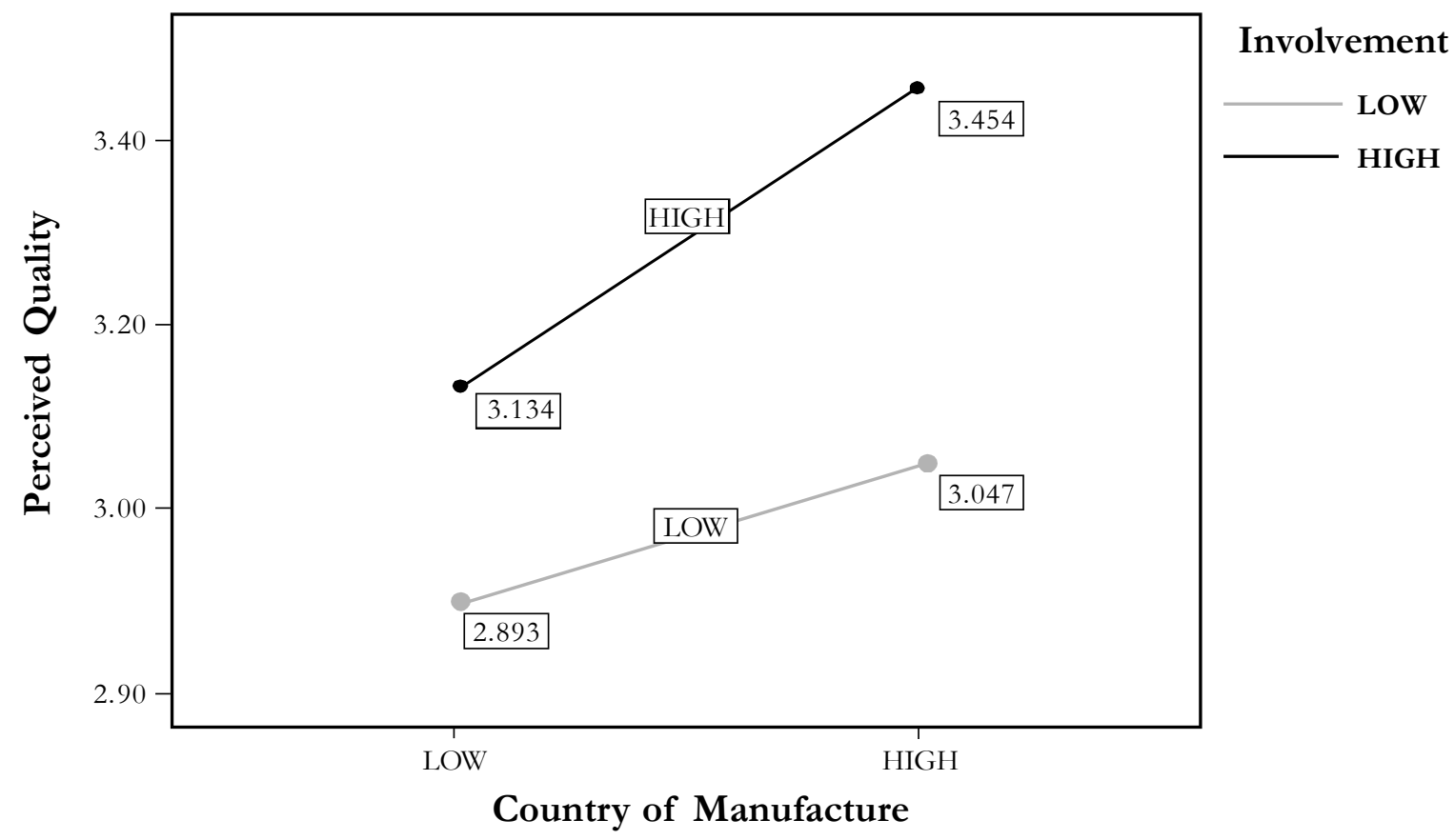

\section{Conclusion}

It can be concluded that the country of manufacture is seen as the more important factor than the country of design, when assessing the perceived quality of a perfume. This result proved to be consistent with the moderating variable's analysis, that shows both high and low levels of consumers' involvement assumes that the manufacturing location is an important consideration, and therefore the consumers' influence does not moderate its effect. However, consumer involvement does moderate the influence of the country of design on the perceived value, since only those with a high consumer involvement consider this variable when they assess a product's perceived quality.

This study uses only one type of product and measures the perceived quality as a 
unidimensional variable, while according to Chowdhury and Ahmed (2009), perceived quality variables are divided into two dimensions, namely the perceived qualities of the design, and the manufacture of the products. This study uses a median split as a method to divide the participants into groups with high and low levels of involvement, which might create bias due to such grouping. The results may differ significantly when another method is employed.

Experimental design studies allow for the presence of confounding background variables, therefore gender, as a souce of a background variable, was controlled for by providing two types of perfume for men and women in the experimental tools. With the presence of two perfumes, the internal validity can be assured since there is no selection bias occurring due to the influence of gender, as is also shown by the assessment of the effects of possible background factors on the quality of the products. Internal validity is also secured by using a random assignment to prevent such threats (Christensen 1988:. 174).

This study has several theoretical implications. This study shows that during a product's perceived quality assessment, consumers are able to distinguish the country of origin as a multidimensional variable. The country of manufacture of the product, better known by the term "made in" is a more important consideration than the country of design. Then, the consumers' involvement only acts to strengthen the effects of the country of design on the product's perceived quality, since the country of design only works on products with high consumer involvement.

The practical implications of this study show that the country of manufacture is highly perceived as being more powerful in influencing the quality of a product than its country of design. Therefore, "made in" information is important and needs to be put on the product's labeling or advertising to make it easier for consumer to have knowledge of it. Marketers should understand which countries are perceived as superior countries for the manufacturing of their products. This may well be different for different categories of products as well as potential market groups. Furthermore, information of the country of design should also be considered for inclusion on the promotional tools since it works for products with high levels of consumer involvement.

\section{Suggestion}

Based on the research conducted there are some suggestions, we can make. This study was conducted to demonstrate that the country of manufacture of products plays an important role in influencing the quality of the product, which is in line with previous empirical studies (Essousssi 2010). The developing countries have growing numbers of consumers who tend to use products which are made in developed countries, or are from countries that are perceived as being superior in making the products. So, it is important to conduct further comparative research to analyze how consumers in different countries, with different backgrounds, such as their cultural and social economic factors, would see the multiple dimensions of the country of origin of a product.

Experimental design was applied here to get a value for the internal validity of the research by controlling the other variables that can lead to confusing effects. On the other hand, this approach causes weaknesses that decrease the natural aspects of the research's 
conduct, ultimately leading to limited generalizations. This also means there is a tradeoff between the internal and external validity, as experimental design was developed to increase the internal validity, and will, by its very nature, decrease the external validity
(Christensen 1988: 173, 403). Therefore, it is important to carry out further studies to get a wider view of the generalization by conducting surveys designed for multidimensional country of origin topics in developing countries.

\section{References}

Aaker, D. A. 1991. Managing Brand Equity: Capitalizing on the Value of a Brand Name. New York: The Free Press.

Abraham, V. 2013. Does consumer animosity impact purchase involvement? An empirical investigation. International Journal of Business and Social Science 4 (1): 1-11.

Ahmed, S. A., and A. D'astous. 2008. Antecedents, moderators and dimensions of country of origin evaluations. International Marketing Review 25 (1): 75-106.

Charitaou, M., P. Lois, and H. B. Santoso. 2012. The relationship between working capital management and firm's profitability: An empirical investigation for an emerging Asian country. International Business and Economics Research Journal 11 (8): 839-847.

Chowdhury, D. K., and J. U. Ahmed. 2009. An examination of the effect of partitioned country of origin on consumer product quality perceptions. International Journal of Consumer Studies: 496-502.

Chowdhury, M. K. H. 2010. The cognitive foundations of partitioned country-of-origin: A causal path analysis. International Journal of Marketing Studies 2 (2): 259-263.

Chowdhury, M. K. H., and K. Biswas. 2011. Effects of price and country of origin on consumer product quality perceptions: An empirical study in Bangladesh. International Journal of Management 28 (3): 659674.

Chueh, T. Y., and D. T. Kao. 2004. The moderating effects of consumer perception to the impacts of country-of-design on perceived quality. Journal of American Academy of Business (March): 70-74.

Christensen, L. B. 1988. Experimental Methodology (4 ${ }^{\text {th }}$ ed.). London: Allyn and Bacon, Inc.

Dodds, W. B., K. B. Monroe, and D. Grewal. 1991. Effects of price, brand, and store information on buyers' product evaluations. Journal of Marketing Research 28: 307-319.

Essoussi, L.H., and D Merunka. 2007. Consumers' product evaluation in emerging markets; does country of design, country of manufacture, or brand image matter. International Marketing Review 24 (4): 409-426.

Essoussi, L. H. 2010. Technological complexity and country of origin effects on binational product evaluation: Investigation in an emerging market. Journal of Global Marketing 23: 306-320.

Fah, B. C. Y., Y. S. Foon, Y.S., and S. Osman. 2011. An exploratory study of the relationships between advertising appeals, spending tendency, perceived social status and materialism on perfume purchasing behavior. International Journal of Business and Social Science 2 (10): 202-208. 
Fischer, N. K., A. Diamantopoulos, and K. Oldenkotte. 2012. Are consumers really willing to pay more for a favorable country image? A study of country-of-origin effects on willingness to pay. Journal of International Marketing 20 (1): 19-41.

Hamzaoui, L., and D. Merunka. 2006. The impact of country of design and country of manufacture on consumer perception of bi-national products' quality: An empirical model based on the concept of fit. Journal of Consumer Marketing 23 (3): 145-155.

Henderson, S., and S.F. Haque. 2010. The ethnicity impact on attitudes toward country of origin for products with different involvement level. Journal of International Consumer Marketing 22: 271-291.

Jain, K., and N. Srinivasan. 1994. An empirical assessment of multiple operationalizations of involvement. Advances in Consumer Research 17: 594-602.

Josiassen, A. 2010. Young Australian consumers and the country-of-origin effect: Investigation of the moderating roles of product involvement and perceived product-origin congruency. Australian Marketing Journal: 23-27.

Josiassen, A., B. A., Lukas, B.A., and G. J. Whitwell. 2008. Country of origin contingencies competing perspectives on product familiarity and product involvement. International Marketing Review 25 (4): 423-440.

Keegan, W., and M. Green .2011. Global Marketing Management $\left(6^{\mathrm{ed}}\right)$. Upper Saddle River, New Jersey: Prentice Hall Inc.

Kotler, P., and K. Kevin. 2013. Marketing Management (4 ${ }^{\text {th }}$ ed.). Pearson Education Limited.

Laurent, G., and J. N. Kapferer. 1985. Measuring consumer involvement profiles. Journal of Marketing Research 22 (1) : 41-53

Lee, W. N., T. W. Yun, and B. K. Lee. 2005. The role of involvement in country of origin effects on product evaluation: Situational and enduring involvement. Journal of International Consumer Marketing 17: 51-67.

Liefeld, J. 1993. Experiments on country of origin effects: Review and meta-analysis of effect size, product country images: Impact role in international marketing. In Nicholas, P., and H. Louise (Ed), International Business Press: 117-1156. New York.

Moeran, B. 2005. Japanese fragrance descriptive and gender constructions: Preliminary steps towards an anthropology of olfaction. Etnofoor 18 (1): 97-123.

Montlake, S. 2013. 'Southeast Asia's silver-haired tycoons. Forbes Asia, 5 March, 29-29.

Nahartyo, E. 2012. Desain dan Implementasi Riset Ekesperimen. Yogyakarta: UPP STIM YKPN.

Pharr, J. M. 2005. Synthesizing country of origin research from the last decade: Is the concept still salient in an era of global brands? Journal of Marketing Theory and Practice 13 (4): 34-45.

Parker, P. M. 2011. The 2011 Import and Export Market for Perfumes and Toilet Waters in Asia. www.icongrouponline.com.

Sadeghi, T., K. G. Tabrizi, and A. Noroozi. 2011. The effective factors related with feelings, brand perception and purchase decision under model. African Journal of Business Management 5 (30): 1202512030.

Saffu, K., and D. Scott. 2009. Developing country perceptions of high and low involvement products manufactured in other countries. International Journal of Emerging Markets 4 (2): 185-199. 
Seitz, V. 1998. Direct response advertising in The US and European markets; a content analysis of fashion products. European Business Review: 268-275.

Sekaran, U. and R. Bougie. 2010. Research Methods for Business A skill Building Approach (5 ${ }^{\text {th }}$ ed.). United Kingdom: John Wiley \& Sons Ltd.

Syahlani, S. P., dan A.C Citra. 2008. Efek merek domestik vs Asing dan informasi country of origin terhadap persepsi dan sikap konsumen. Jurnal Ekonomi dan Bisnis Indonesia 23 (2).

Thompson, C. J. and D. L. Haytko. 1997. Speaking of fashion: consumers' uses of fashion discourses and the appropriation of countervailing cultural meanings. Journal of Consumer Research 24 (6): 15-94.

Tsang, A. S. L., G. P. Prendergast, and C. N. W. Chan. 2010. The interactive influence of country of origin of brand and product involvement on purchase intention. Journal of Consumer Marketing 27 (2): 180188.

Voorhees, T. 2013. The role and measurement of quality factors in competition analysis. In Round Table Organization for Economic Cooperation Competition. France.

Wong, C. Y., M. J. Polonsky, and R. Garma. 2008. The impact of consumer ethnocentrism and country of origin sub- components for high involvement products on young Chinese consumers' product assessments. Asia Pacific Journal of Marketing 20 (4): 455-478.

Zeithaml, V. 1988. Consumer perception of price, quality and value: Means end model and synthesis of evidence. Journal of Marketing 52 (3): 2-21. 